\section{An Unbiased Approach to Discover Novel Therapies for Liver Disease}

\section{Colleen Croniger ${ }^{1 *}$}

Alcoholic liver disease (ALD) represents a range of clinical and morphological changes that range from steatosis to inflammation and necrosis (alcoholic hepatitis) to progressive fibrosis (alcoholic cirrhosis) [1]. Most chronic heavy drinkers exhibit steatosis characterized by greater amount of macrovesicular fat content than microvesicular fat. In addition hepatocyte ballooning degeneration with mixed lobular inflammation is evident [2,3]. Patients with ALD also have elevated serum concentrations of alanine aminotransferase (ALT) and aspartate aminotransferase (AST), which are evidence of liver injury. The severity of disease is not always correlated with the amount of alcohol consumed. In fact, most long-term heavy drinkers develop steatosis, but only $20-30 \%$ of these patients develop hepatitis, and less than $10 \%$ will progress to cirrhosis [4-6].

Nonalcoholic fatty liver disease (NAFLD) can progress from steatosis to inflammation called nonalcoholic steatohepatitis (NASH) [7] without consumption of alcohol. Patients with NASH also have elevated serum concentrations of ALT and AST. Liver histology from patients with NASH is identical to those found in alcohol-induced steatohepatitis (ASH). Obesity and insulin resistance are highly associated with liver disease in patients with NASH suggesting that the mechanism of liver injury in NASH may be different than in ASH. However, the mechanism that causes mild steatosis to progress to more severe forms of liver disease in a subset of the population is still unclear.

When a patient develops liver disease, they exhibit symptoms of hepatic steatosis and inflammation with insulin resistance; therefore it is difficult to tease out the contribution of only obesity or insulin resistance to the development of disease in humans. Thus, the need for suitable animal models is necessary for us to better understand the role of each of these factors in ASH and NASH. Current genetic animal models for steatosis focus on single gene mutations that promote increased lipogenesis or decreased fatty acid oxidation. Models for increased fatty acid synthesis include leptin deficiency $(o b / o b)$, lack of leptin receptor $(d b / d b)$, and altered leptin receptor signaling $(f a / f a)$. Leptin is a key regulator in the brain for hunger that is produced in adipose tissue. Lack of the leptin or leptin receptor results in hyperphagia causes obesity, steatosis and insulin resistance [8-10]. Another animal model for steatosis has disrupted melanocortin receptor signaling in the hypothalamus of the brain which regulated appetite, body weight and insulin secretion.

\footnotetext{
*Corresponding author: Colleen Croniger, $\mathrm{PhD}$, Department of Nutrition, Case Western Reserve University, Cleveland Ohio 44107, USA, Tel: +1-216-3684967; Fax: +1-216-368-6644; E-mail: cmc6@case.edu
}

Received: June 12, 2012 Accepted: June 13, 2012 Published: June 15, 2012
Disruption of melanocortin signaling by deletion of melanocortin 4 receptor (MC4-RKO) causes obesity, steatosis and insulin resistance $[11,12]$. Other genetic animal models have mutations that decrease lipid removal. The peroxisome proliferator receptor a knockout mice (PPARa-/-) have reduced fatty acid oxidation. PPARa is a hepatic transcription factor that regulates the transcription of mitochondrial and peroxisomal $\beta$-oxidation genes. The enzyme, acyl CoA oxidase (AOX), is the first enzyme in the peroxisomal $\beta$-oxidation pathway. Acyl CoA oxidase knockout mice (AOX-/-), have reduced fatty acid oxidation and develop severe hepatic steatosis due to the intrahepatic accumulation of long-chain fatty acids. This results in steatohepatitis and liver tumors [13]. These are just some of the animal models that have been studied and are by no means a comprehensive review.

In addition to single gene models, wild type or inbred strains of mice, such as $\mathrm{C} 67 \mathrm{Bl} / 6 \mathrm{~J}$ have been manipulated by diet to develop obesity, steatosis and inflammation. This suggests that both genetics and environmental factors can increase hepatic lipogenesis and steatosis. Dietary models of steatosis commonly used are methioninerestricted choline-deficient diet (MCD) and the high fat simple carbohydrate (HFSC) diet. The MCD, which is high in sucrose and fat (40\% sucrose and $10 \%$ fat) but lacks methionine and choline that are necessary for hepatic beta oxidation and very low-density lipoprotein (VLDL) production $[14,15]$. This model produces steatohepatitis, inflammation and liver fibrosis that are histologically similar to NASH in humans but the animals lose significant weight. The mice also do not develop peripheral insulin resistance, which is evident in patients with NASH $[16,17]$. Thus, the MCD diet is not reflective of the human disease.

The HFSC diet (26\% kcal sucrose, 58\% kcal fat, $16 \% \mathrm{kcal}$ protein) produces obesity and insulin resistance in some inbred strains of mice. The mouse strain, C57BL/6J (abbreviated B6) is a well-accepted model of diet-induced obesity [18]. We and others have shown that the $\mathrm{B} 6$ male mice fed a HFSC diet for 16 weeks have increased their body weight by $15 \%$, develop steatosis and become insulin resistant, while the $\mathrm{A} / \mathrm{J}$ male mice remain lean and have no accumulation of hepatic lipids $[18,19]$. We also have demonstrated that after 400 days on the HFSC diet, the livers of B6 male mice had progressed from steatosis to NASH and hepatacellular carcinoma (HCC); yet the $\mathrm{A} / \mathrm{J}$ male mice remained resistant to these conditions. Thus, relative to $\mathrm{A} / \mathrm{J}$ male mice, the $\mathrm{B} 6$ male mice have a genetic susceptibility to developing diet-induced steatosis, which progresses to severe liver injury after long-term exposure to the HFSC diet [20]. This long-term diet study is very similar to the human disease, but it would be difficult to identify quantitative trait loci (QTLs) modulating development of HCC since the diet study is expensive to perform.

How can we identify new genes and pathways for the development of ASH and NASH that mimic the human disease yet are cost effective? With the development of chromosome substitution strains (CSS) we are able to have an unbiased approach for identification of genes involved in the development of liver disease. The $\mathrm{B} 6-\mathrm{Chr}^{\mathrm{A} / \mathrm{j}} \mathrm{CSS}$ panel was constructed by crossing B6 (recipient genome) and $\mathrm{A} / \mathrm{J}$ (donor genome) mice [21,22]. We have surveyed the panel of CSS to identify genes that modulate obesity, insulin resistance and liver 
steatosis [23]. The advantages to using CSS strains with an isogenic $\mathrm{A} / \mathrm{J}$ chromosome over a traditional F1 hybrid cross between B6 and $\mathrm{A} / \mathrm{J}$ strains are 1) ability to identify both dominant and recessive genes modulating liver injury 2) the ability to have genetically identical mouse strain to continue studying and 3) ability to decouple phenotypes and investigate their contribution individually. Finally, with the discovery of novel genes and pathways from the CSS we can return to the human genome and determine if the single nucleotide polymorphisms (SNPs) in the mice are associated with liver disease in the human population. This will allow us to identify new genes and pathways in an unbiased manner and eventually develop novel therapies for the prevention and treatment of liver disease in a timely and cost effective manner.

\section{References}

1. Tome S, Lucey MR (2004) Review article: current management of alcoholic liver disease. Aliment Pharmacol Ther 19: 707-714.

2. McClain CJ, Mokshagundam SP, Barve SS, Song Z, Hill DB, et al. (2004) Mechanisms of non-alcoholic steatohepatitis. Alcohol 34: 67-79.

3. McClain C, Hill D, Schmidt J, Diehl AM (1993) Cytokines and alcoholic liver disease. Semin Liver Dis 13: 170-182.

4. Sørensen TI, Orholm M, Bentsen KD, Høybye G, Eghøje K, et al. (1984) Prospective evaluation of alcohol abuse and alcoholic liver injury in men as predictors of development of cirrhosis. Lancet 2: 241-244

5. Teli MR, Day CP, Burt AD, Bennett MK, James OF (1995) Determinants of progression to cirrhosis or fibrosis in pure alcoholic fatty liver. Lancet 346 : 987-990.

6. Corrao G, Aricò S, Zambon A, Torchio P, Lepore AR, et al. (1997) Is alcoho a risk factor for liver cirrhosis in HBsAg and anti-HCV negative subjects? Collaborative Groups for the Study of Liver Diseases in Italy. J Hepatol 27 470-476.

7. Ludwig J, Viggiano TR, McGill DB, Oh BJ (1980) Nonalcoholic steatohepatitis: Mayo Clinic experiences with a hitherto unnamed disease. Mayo Clin Proc 55: $434-438$

8. Angulo P (2002) Nonalcoholic fatty liver disease. N Engl J Med 346: 1221 1231.

9. Browning JD, Horton JD (2004) Molecular mediators of hepatic steatosis and liver injury. J Clin Invest 114: 147-152.

10. Clark JM, Brancati FL, Diehl AM (2003) The prevalence and etiology of elevated aminotransferase levels in the United States. Am J Gastroenterol 98: $960-967$

11. Butler AA, Cone RD (2001) Knockout models resulting in the development of obesity. Trends Genet 17: S50-S54.

12. Huszar D, Lynch CA, Fairchild-Huntress V, Dunmore JH, Fang Q, et al. (1997) Targeted disruption of the melanocortin-4 receptor results in obesity in mice. Cell 88: 131-141.

13. Fan CY, Pan J, Chu R, Lee D, Kluckman KD, et al. (1996) Hepatocellular and hepatic peroxisomal alterations in mice with a disrupted peroxisomal fatty acyl-coenzyme A oxidase gene. J Biol Chem 271: 24698-24710.

14. Anstee QM, Goldin RD (2006) Mouse models in non-alcoholic fatty liver disease and steatohepatitis research. Int J Exp Pathol 87: 1-16.

15. Chawla RK, Watson WH, Eastin CE, Lee EY, Schmidt J, et al. (1998) S-adenosylmethionine deficiency and TNF-alpha in lipopolysaccharideinduced hepatic injury. Am J Physiol 275: G125-G129.

16. Ip E, Farrell GC, Robertson G, Hall P, Kirsch R, et al. (2003) Central role of PPARalpha-dependent hepatic lipid turnover in dietary steatohepatitis in mice. Hepatology 38: 123-132.

17. Leclercq IA, Farrell GC, Field J, Bell DR, Gonzalez FJ, et al. (2000) CYP2E1 and CYP4A as microsomal catalysts of lipid peroxides in murine nonalcoholic steatohepatitis. J Clin Invest 105: 1067-1075.

18. Black BL, Croom J, Eisen EJ, Petro AE, Edwards CL, et al. (1998) Differential effects of fat and sucrose on body composition in $\mathrm{A} / \mathrm{J}$ and $\mathrm{C} 57 \mathrm{BL} / 6$ mice. Metabolism 47: 1354-1359.

19. Rebuffé-Scrive M, Surwit R, Feinglos M, Kuhn C, Rodin J (1993) Regional fat distribution and metabolism in a new mouse model (C57BL/6J) of non-insulindependent diabetes mellitus. Metabolism 42: 1405-1409.

20. Hill-Baskin AE, Markiewski MM, Buchner DA, Shao H, DeSantis D, et al. (2009) Diet-induced hepatocellular carcinoma in genetically predisposed mice. Hum Mol Genet 18: 2975-2988.

21. Singer JB, Hill AE, Burrage LC, Olszens KR, Song J, et al. (2004) Genetic dissection of complex traits with chromosome substitution strains of mice. Science 304: 445-448.

22. Belknap JK (2003) Chromosome substitution strains: some quantitative considerations for genome scans and fine mapping. Mamm Genome 14: 723732

23. Millward CA, Burrage LC, Shao H, Sinasac DS, Kawasoe JH, et al. (2009) Genetic factors for resistance to diet-induced obesity and associated metabolic traits on mouse chromosome 17. Mamm Genome 20: 71-82.

\section{Author Affiliation}

${ }^{1}$ Department of Nutrition, Case Western Reserve University, Cleveland Ohio 44107, USA

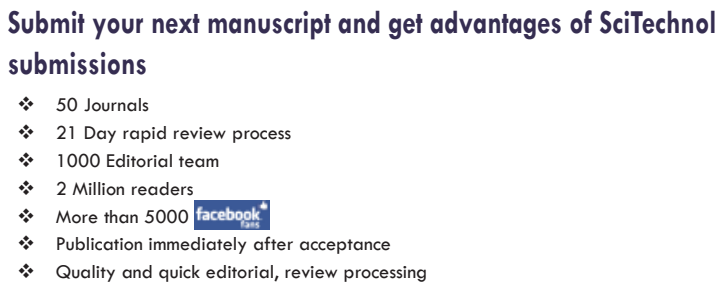

Submit your next manuscript at • www.scitechnol.com/submission 